\title{
Comparative Study of Microwave Assisted and Conventional Synthesis of Tp*-Complexes
}

\author{
Hamed Aboajila Alqamoudy ${ }^{*}$, Hussain Ibrahim Alarabi \\ Chemistry Department, Faculty of Science, Zawia University, Az Zawiyah, Libya \\ Email address: \\ hamed_alqamoudy@yahoo.com (H. A. Alqamoudy) \\ ${ }^{*}$ Corresponding author
}

To cite this article:

Hamed Aboajila Alqamoudy, Hussain Ibrahim Alarabi. Comparative Study of Microwave Assisted and Conventional Synthesis of Tp*Complexes. Journal of Photonic Materials and Technology. Vol. 4, No. 1, 2018, pp. 19-25. doi: 10.11648/j.jmpt.20180401.14

Received: January 20, 2018; Accepted: February 8, 2018; Published: February 28, 2018

\begin{abstract}
Cobalt, copper and nickel complexes with tris(3,5-dimethyl-1H-pyrazol-1-yl)hydroborate (Tp*) were synthesized by the reaction of potassium tris(3,5-dimethyl-1H-pyrazol-1-yl)hydroborate $\left(\mathrm{KTp}^{*}\right)$ with the corresponding metal(II) chloride by using conventional reflux methods and microwave methods. The two methods were compared and the microwave method was found to be less time consuming and gave higher yields.
\end{abstract}

Keywords: Pz* [3,5-dimethyl-1H-pyrazol-1-yl], KTp* [potassium tris(3,5-dimethyl-1H-pyrazol-1-yl)hydroborate], Tp*-complexes, [tris(3,5-dimethyl-1H-pyrazol-1-yl)hydroborate complexes]

\section{Introduction}

Pyrazole-derived ligands, known collectively as poly (pyrazolyl) ligands, are derived from two or more $\mathrm{N}$ deprotonated pyrazole rings bound to a main group atom through one of the ring nitrogens [1]. The basic skeleton of the ligand involves pyrazole units bonded to a main group apex via the nitrogen atoms at the dis- placement of hydrogen [2]. Tris(pyrazolyl) borate $\left(\mathrm{Tp}^{\mathrm{x}}\right)$ ligands, known as scorpionates, have attracted considerable attention and proven to be extremely popular ligands since their introduction by Trofimenko in 1967 [3-4]. They constitute one of the most widely used group of ligands in chemistry. The reaction of $\mathrm{KTp}^{*}$ ligands with metal ions is expected to give either tetrahedral or octahedral complexes depending on the reactant ratios and the nature of the metal ion.

Reactions of Tp complexes have been investigated. Studies included the synthesis of complexes containing $\mathrm{Tp}$ in addition to other ligands with some metals such as $\mathrm{Ni}(\mathrm{II})$, $\mathrm{Co}(\mathrm{II})$ and $\mathrm{Mn}(\mathrm{II})$.

Michiue and Jordan have shown that reaction of the TlTpMs and TlTpMs* With $\mathrm{MCl}_{4}(\mathrm{M}=\mathrm{Zr}$, Hf $)$ in toluene affords $\left[\mathrm{ZrTpMsCl}_{3}\right],\left[\mathrm{ZrTpMs}{ }^{*} \mathrm{Cl}_{3}\right]$ and $\left[\mathrm{HfTpMs} * \mathrm{Cl}_{3}\right]$. The complex $\left[\mathrm{ZrTpMsCl}_{3}\right]$ exhibits extremely high activity for ethylene polymerization and ethylene/hexane copolymerization. Also, a series of $\mathrm{TpxMCl}_{3}$ complexes $(\mathrm{M}=\mathrm{Ti}, \mathrm{Zr}, \mathrm{Tpx}=\mathrm{TpNp}, \mathrm{TpPh}, \mathrm{TptBu})$ have been synthesized [5]. The heteroleptic picolinic acid N-oxide complexes, $\left[\operatorname{Ln}(\mathrm{Tp})_{2}(\mathrm{pnx})\right],(\mathrm{Ln}=\mathrm{Y}, \mathrm{Eu}, \mathrm{Gd}, \mathrm{Tb}, \mathrm{Er}, \mathrm{Yb}$ or $\left.\mathrm{Lu}),\right)$ have been prepared and characterized [6]. [Tp* $\left.\mathrm{VCl}_{2} \mathrm{~L}\right] \mathrm{L}=4$ substited pyridine $\mathrm{N}-\mathrm{C}_{5} \mathrm{H}_{4}-\mathrm{R}\left(\mathrm{R}=\mathrm{H}, \mathrm{CH}_{3}, \mathrm{C}_{2} \mathrm{H}_{5}, \mathrm{Ph}\right)$ were prepared by replacing the dimethylformamide ligand in $\mathrm{Tp} * \mathrm{VCl}_{2}(\mathrm{DMF})$ by various $\mathrm{N}$-containing hetcrocycles [7]. Xing and co-workers have prepared the new oxovanadium(IV) complexes $\mathrm{VO}\left(\mathrm{HB}(\mathrm{Pz})_{3}\right)\left(\mathrm{H}_{2} \mathrm{~B}(\mathrm{Pz})_{2}\right)$ and $\mathrm{VO}\left(\mathrm{B}(\mathrm{Pz})_{4}\right)$ [8]. Chromium(III) complexes containing $\mathrm{Tp}$ ligands $\left[\mathrm{Cr}(\mathrm{Tp})_{2}\right]\left[\mathrm{CrCl}_{3}(\mathrm{Tp})\right], \quad\left[\mathrm{CrCl}_{2}(\mathrm{Tp})(\mathrm{THF})\right]$ and $\left[\mathrm{HPMe}_{3}\right]\left[\mathrm{CrCl}_{3}(\mathrm{Tp})\right]$ have been synthesized [9]

The compound $\mathrm{Tp} * \mathrm{MoI}(\mathrm{CO})_{2} \cdot 2 \mathrm{CH}_{3} \mathrm{CN}$ has been isolated from the reaction between $\left[\mathrm{MoI}_{2}(\mathrm{CO})_{3}(\mathrm{MeCN})_{2}\right]$ and $\mathrm{KTp} *$, and has been described as a diamagnetic compound, showing well-defined ${ }^{1} \mathrm{H}$ NMR spectroscopic properties [10]. Carrillo and co-workers have reported the synthesis of [TpxMo(NNPhR $\left.)_{2} \mathrm{Cl}\right] \mathrm{R}=\mathrm{Ph}, \mathrm{Me}, \mathrm{TpX}=\mathrm{Tp}, \mathrm{Tp}{ }^{*}[11]$.

$\left[\mathrm{Tp} * \mathrm{~W}(\mathrm{OPh})\left\{\mathrm{S}_{2} \mathrm{C}_{2}\left(\mathrm{CO}_{2} \mathrm{Me}\right)_{2}\right] \quad\right.$ and $\left[\mathrm{Tp} * \mathrm{~W}(\mathrm{SePh})\left\{\mathrm{S}_{2} \mathrm{C}_{2}(\mathrm{Ph})(2-\right.\right.$ quinoxalinyl $\left.)\right]$ have been synthesized and determined by X-ray crystallography [12]. $\mathrm{Zn}\left(\mathrm{Tp}^{*}\right) \mathrm{Cl} \quad\left(\mathrm{Tp}^{*}=\operatorname{tris}(3,5\right.$-dimethyl-1-pyrazolyl)borate) was investigated [13]. (3-NH(t-butyl)-5-methyl-pyrazole) ${ }_{\mathrm{n}} \mathrm{MX}_{2}$ $(\mathrm{M}=\mathrm{Zn}, \mathrm{Ni}, \mathrm{Co}, \mathrm{Mn} ; \mathrm{n}=3,4 ; \mathrm{X}=\mathrm{Cl}, \mathrm{Br})$ have been synthesized [14]. $\left[\mathrm{Cu}(\mathrm{NCS})_{2} \mathrm{~L}^{1}\right], \quad\left[\mathrm{Mn}(\mathrm{NCS})_{2} \mathrm{~L}^{1}\right]$, 
$\left[\mathrm{Mn}(\mathrm{NCS})_{2} \mathrm{~L}^{2}\right]$ and $\left[\mathrm{Zn}(\mathrm{NCS}) \mathrm{L}^{2}\right]_{2}\left[\mathrm{Zn}(\mathrm{NCS})_{4}\right]$ complexes have been synthesized, $\mathrm{L}^{1}=\operatorname{bis}(1-(3,5-$ dimethylpyrazolyl)methyl)amine, $\quad \mathrm{L}^{2}=\operatorname{tris}(1-(3,5-$ dimethylpyrazolyl)methyl)amine [15]. The V(III) complex $\left[\mathrm{V}\left(\mathrm{Tp}^{\mathrm{tBu2}}\right) \mathrm{Cl}_{2}\right]$ has been synthesized by the reaction of $\left[\mathrm{VCl}_{3}(\mathrm{THF})_{3}\right]$ (prepared in situ) and $\mathrm{K}\left(\mathrm{Tp}^{\mathrm{tBu} 2}\right), \mathrm{Tp}^{\mathrm{tBu} 2}=$ hydrotris(3,5-di-tert-butylpyrazolyl)borate) [16].

Microwave-assisted synthesis is, in many ways, superior to traditional heating. The ability to elevate the temperature of a reaction well above the boiling point of the solvent increases the speed of reactions. Reactions are thus completed in minutes or even seconds. Yields are generally higher and the technique may provide a means of synthesizing compounds that is not available conventionally.

In a dedicated microwave reactor, reactions can be run in sealed vials under carefully controlled conditions at temperatures up to $200^{\circ} \mathrm{C}$ and pressures up to 20 bar. This provides the means to heat reactions much higher than conventional open-vessel conditions, in which the maximum temperature is limited to the boiling point of the solvent.

High-speed synthesis with microwaves has attracted aconsiderable amount of attention in recent years [17]. More than 2000 articles have been published in the area of microwave assisted organic synthesis (MAOS) since the first reports on the use of microwave heating to accelerate organic chemical transformations by the groups of Gedye and Giguere/ Majetich in 1986 [18-19]. The initial slow uptake of the technology in the late 1980s and early 1990s has been attributed to its lack of controllability and reproducibility, coupled with a general lack of understanding of the basics of microwave dielectric heating. The risks associated with the flammability of organic solvents in a microwave field and the lack of available systems for adequate temperature and pressure controls were major concerns [20].

In this work, we present a method for synthesizing complexes containing $\left(\mathrm{KTp}^{*}\right)$ ligand and some transition metal atoms, (Tp*-Metal), using reflux methods and microwave techniques with a comparison between the two methods.

\section{Experimental}

\subsection{Chemicals and Materials}

All solvents used (N-hexane, petroleum ether, Chloroform, Methanol, Toluene, Ether and Acetone) were obtained from different companies and they were dried by standard methods and distilled prior to use.

The chemicals used for the synthesis were reagent grade (Table 1).

Table 1. List of chemicals used for the synthesis.

\begin{tabular}{llll}
\hline Chemicals & Formula & Molecular weight & Company \\
\hline Coppr chloride dihydrate & $\mathrm{CuCl}_{2} \cdot 2 \mathrm{H}_{2} \mathrm{O}$ & 170.48 & BDH chemicals Ltd Poole England \\
Cobalt chloride hexahydrate & $\mathrm{CoCl}_{2} \cdot 6 \mathrm{H}_{2} \mathrm{O}$ & 237.93 & Avonchem - Khem King \\
Nickel chloride hexahydrate & $\mathrm{NiCl}_{2} \cdot 6 \mathrm{H}_{2} \mathrm{O}$ & 237.69 & Khem King \\
Potassium tetraborohydrate & $\mathrm{KBH}_{4}$ & 170.4 & Rledel-dehaen AG seelze-Hannover \\
Hydrazine sulphate & $\mathrm{H}_{6} \mathrm{~N}_{2} \mathrm{SO}_{4}$ & 130.12 & BDH chemicals Ltd Poole England \\
2,4-pentanedione & $\mathrm{C}_{5} \mathrm{H}_{8} \mathrm{O}_{2}$ & 100.12 & Avocado Research chem. calsLtd \\
Potassium carbonate & $\mathrm{K}_{2} \mathrm{CO}_{3}$ & 138.21 & Alfa Aesar \\
\hline
\end{tabular}

\subsection{Instrumentations}

Melting points were determined by using Electrothermal Digital Melting Point Apparatus model IA 9100.

Infrared spectra were recorded on IR spectrometer Varian 660. All the $\mathrm{Tp}^{*}$-Complexes were in $\mathrm{KBr}$ pellet for the measurement.

Mass spectra and Elemental analyses $(\mathrm{C}, \mathrm{H}, \mathrm{N})$ were performed at the micro analytical center of Cairo University.

${ }^{13} \mathrm{C}$ NMR and ${ }^{1} \mathrm{H}$ NMR spectra were recorded on a Bruker at $400 \mathrm{MHz}$ spectrometer. Chemical shifts are reported in ppm relative to tetramethylsilane (TMS).

Microwave assisted syntheses were carried out by using Milestone Microwave.

\subsection{Syntheses}

\subsubsection{The Ligand; Potassium Tris(3,5dimethyl pyrazolyl) Hydroborate (KTp*)}

Potassium tris(3,5dimethyl pyrazolyl) hydroborate (KTp*) was synthesized with the use of microwave according to the method described in a previous publication [21]. (Yield: 90 \%); m.p: $>380^{\circ} \mathrm{C}$. IR $\left(\mathrm{cm}^{-1}\right)$ : v(BH) 2436, v(CH) 2862,
2925, 2960; ${ }^{1} \mathrm{H}$ NMR (DMSO): $\delta 2.05\left(9 \mathrm{H}, \mathrm{CH}_{3}\right), \delta 3.17$ $\left(9 \mathrm{H}, \mathrm{CH}_{3}\right), \delta 5.53(3 \mathrm{H}, \mathrm{CH}), \delta 8.53(1 \mathrm{H}, \mathrm{BH}) ;{ }^{13} \mathrm{C} \mathrm{NMR}$ (DMSO): $\delta 12.4$ (C4), 13.7(C5), 103.2 (C2),141.9 (C1), $144.6(\mathrm{C} 3)$.

\subsubsection{Synthesis of Metal-Tp* Complexes}

\section{(i) Complex of Tp* with Cobalt (II) Chloride (H1)}

Two methods were adopted in the synthesis of complex (H1):

\section{Method A (reflux):}

A solution of $0.6022 \mathrm{~g}$ of KTp* $(1.79 \mathrm{mmole}, 10 \mathrm{ml} \mathrm{MeOH})$ was added drop wise to a stirred solution of $0.4822 \mathrm{~g}$ of cobalt (II) chloride $(2.02 \mathrm{mmole}, 10 \mathrm{ml} \mathrm{MeOH})$ in a $50 \mathrm{~mL}$ round bottom flask. The flask was fitted with a condenser and the mixture was stirred at room temperature for $5 \mathrm{~h}$. A blue precipitate was obtained. Recrystallization of the product was carried out in chloroform. Blue crystalline solid was obtained, $83 \%$ yield. (m.p: $170^{\circ} \mathrm{C}$ ); IR $\left(\mathrm{cm}^{-1}\right): v(\mathrm{BH})$ 2511.58, v (CH) 2923.18. MS: $m / z: 391[\mathrm{M}]^{+}, 95\left[\mathrm{C}_{5} \mathrm{H}_{7} \mathrm{~N}_{2}\right]^{+}$, $107\left[\mathrm{BH}\left(\mathrm{C}_{5} \mathrm{H}_{7} \mathrm{~N}_{2}\right)\right]^{+}, 356\left[\mathrm{BH}\left(\mathrm{C}_{5} \mathrm{H}_{7} \mathrm{~N}_{2}\right)_{3} \mathrm{Co}\right]^{+}$.

Method B (microwave):

A powder mixture of cobalt (II) chloride $(0.3215 \mathrm{~g}$, 
$1.35 \mathrm{mmole})$ and KTp* $(0.4015 \mathrm{~g}, 1.19 \mathrm{mmole})$ was heated in a glass tube in TFM vessel on the rotating balance plate inside the microwave at 750 watt and $80^{\circ} \mathrm{C}$ for $17 \mathrm{~min}$. The rotor was cooled to room temperature. Chloroform was added to the reaction mixture and the product was washed several times with chloroform and filtered. The product was isolated as a blue powder. (Yield: $92 \%$ ); m.p: $170^{\circ} \mathrm{C}$; IR $\left(\mathrm{cm}^{-1}\right): v$ (BH) 2511, v (CH) 2923.

\section{(ii) Synthesis of Nickel-Tp* Complex (H2)}

Two methods were adopted in the synthesis of complex (H2):

\section{Method A (reflux):}

A solution of $0.4099 \mathrm{~g}$ of KTp* (1.21 mmole, $10 \mathrm{ml} \mathrm{MeOH})$ was added drop wise to a stirred solution of $0.3279 \mathrm{~g}$ of nickel (II) chloride $(1.37 \mathrm{mmole}, 10 \mathrm{ml} \mathrm{MeOH})$ in a $50 \mathrm{~mL}$ round bottom flask. The flask was fitted with a condenser and the mixture was stirred at room temperature for $5 \mathrm{~h}$. A purple precipitate was obtained. Recrystallization of the product was carried out in chloroform. Purple crystalline solid was obtained, $78 \%$ yield. (m.p: $\left.>380^{\circ} \mathrm{C}\right)$; IR $\left(\mathrm{cm}^{-1}\right): v(\mathrm{BH})$ 2512.62, v (CH) 2923.14. MS: $m / z: 391[\mathrm{M}]^{+}, 95\left[\mathrm{C}_{5} \mathrm{H}_{7} \mathrm{~N}_{2}\right]^{+}$, $107\left[\mathrm{BH}\left(\mathrm{C}_{5} \mathrm{H}_{7} \mathrm{~N}_{2}\right)\right]^{+}, 355\left[\mathrm{BH}\left(\mathrm{C}_{5} \mathrm{H}_{7} \mathrm{~N}_{2}\right)_{3} \mathrm{Ni}\right]^{+}$.

Method B (microwave):

A powder mixture of nickel (II) chloride $(0.3279 \mathrm{~g}$, $1.37 \mathrm{mmole})$ and KTp* $(0.4099 \mathrm{~g}, 1.21 \mathrm{mmole})$ was heated in a glass tube in TFM vessel on the rotating balance plate inside the microwave at 750 watt and $80^{\circ} \mathrm{C}$ for $17 \mathrm{~min}$. The rotor was cooled to room temperature. Chloroform was added to the reaction mixture and the product was washed several times with chloroform and filtered. The product was isolated as a purple powder. (Yield: $92 \%)$; m.p: $>380^{\circ} \mathrm{C}$; IR $\left(\mathrm{cm}^{-1}\right): v$ (BH) 2512, v (CH) 2923.

\section{(iii) Synthesis of Copper-Tp* Complex (H3)}

Two methods were adopted in the synthesis of complex
(H3):

\section{Method A (reflux):}

A solution of $0.5954 \mathrm{~g}$ of KTp* $(1.77 \mathrm{mmole}, 10 \mathrm{ml} \mathrm{MeOH})$ was added drop wise to a stirred solution of $0.3416 \mathrm{~g}$ of copper (II) chloride $(2.00 \mathrm{mmole}, 10 \mathrm{ml} \mathrm{MeOH})$ in a $50 \mathrm{~mL}$ round bottom flask, The flask was fitted with a condenser and the mixture was stirred at room temperature for $5 \mathrm{~h}$. A green precipitate was obtained. Recrystallization of the product was carried out in chloroform. Dark-green crystalline solid was obtained, $80 \%$ yield. (m.p: $\left.295^{\circ} \mathrm{C}\right)$; IR $\left(\mathrm{cm}^{-1}\right)$ : v (BH) 2513.10, $v \quad(\mathrm{CH})$ 2922.88. $\mathrm{MS}: \quad m / z: \quad 391[\mathrm{M}]^{+}$, 95[ $\left.\mathrm{C}_{5} \mathrm{H}_{7} \mathrm{~N}_{2}\right]^{+}, 107\left[\mathrm{BH}\left(\mathrm{C}_{5} \mathrm{H}_{7} \mathrm{~N}_{2}\right)\right]^{+}, 360\left[\mathrm{BH}\left(\mathrm{C}_{5} \mathrm{H}_{7} \mathrm{~N}_{2}\right){ }_{3} \mathrm{Cu}\right]^{+}$.

\section{Method B (microwave):}

A powder mixture of copper (II) chloride $(0.3416 \mathrm{~g}$, $2.00 \mathrm{mmole})$ and $\mathrm{KTp}^{*}(0.5954 \mathrm{~g}, 1.77 \mathrm{mmole})$ was heated in a glass tube in TFM vessel on the rotating balance plate inside the microwave at 750 watt and $80^{\circ} \mathrm{C}$ for $17 \mathrm{~min}$. The rotor was cooled to room temperature. Chloroform was added to the reaction mixture and the product was washed several times with chloroform and filtered. The product was isolated as a dark-green powder. (Yield: $90 \%$ ); m.p: $295^{\circ} \mathrm{C}$; IR $\left(\mathrm{cm}^{-1}\right): v(\mathrm{BH}) 2513, v(\mathrm{CH}) 2922$.

\section{Results and Discussion}

\subsection{Metal-Tp* Complexes}

The $\mathrm{Co}, \mathrm{Ni}, \mathrm{Cu}$ complexes ( $\mathrm{H} 1$ to $\mathrm{H} 3$ ) were synthesized by reaction of the ligand (KTp*) with the appropriate metal (II) chloride by using conventional reflux methods and microwave methods as shown in figure 1. In the conventional reflux method, all reactions were carried out in methanol where the ligand-metal ratio was 1:1 at room temperature. The complexes were obtained in high yield percentage.

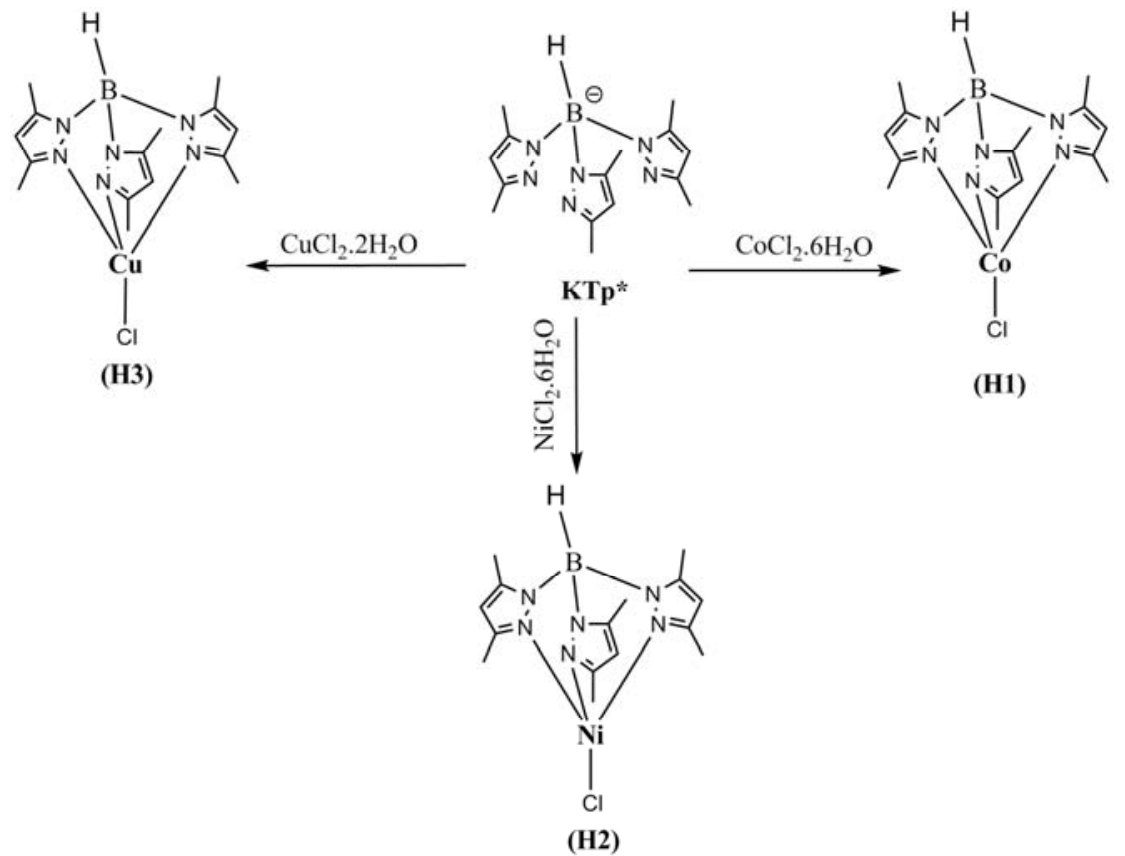

Figure 1. Synthesis of Tp* Complexes (H1 to H3). 
Table 2 shows a comparison between the reflux method and the microwave method in the synthesis of various compounds prepared in this work. This comparison is made in terms of reaction yield and reaction time. As can be seen from the table, it is evident that the microwave method gives higher yields and takes less time. In addition, the microwave method required no solvents. This made the reactions cleaner and the time required to evaporate has been saved.

Table 2. Comparison between the microwave and reflux method.

\begin{tabular}{|c|c|c|c|c|}
\hline \multirow{2}{*}{ Compound } & \multicolumn{2}{|l|}{ Microwave } & \multicolumn{2}{|l|}{ Reflux } \\
\hline & Reaction Time & \%Yield & Reaction Time & \%Yield \\
\hline $\mathrm{H} 1-\mathrm{BH}\left(\mathrm{C}_{5} \mathrm{H}_{7} \mathrm{~N}_{2}\right)_{3} \mathrm{CoCl}$ & $17 \mathrm{~min}$ & $92 \%$ & $5 \mathrm{~h}$ & $83 \%$ \\
\hline $\mathrm{H} 2-\mathrm{BH}\left(\mathrm{C}_{5} \mathrm{H}_{7} \mathrm{~N}_{2}\right)_{3} \mathrm{NiCl}$ & $17 \mathrm{~min}$ & $92 \%$ & $5 \mathrm{~h}$ & $78 \%$ \\
\hline $\mathrm{H} 3-\mathrm{BH}\left(\mathrm{C}_{5} \mathrm{H}_{7} \mathrm{~N}_{2}\right)_{3} \mathrm{CuCl}$ & $17 \mathrm{~min}$ & $90 \%$ & $5 \mathrm{~h}$ & $80 \%$ \\
\hline
\end{tabular}

\subsection{IR Spectroscopy}

Infrared spectroscopy was used in characterization of all compounds synthesized in this work. The IR spectrum of compound (KTp*), figure 2 , shows a band at $2436 \mathrm{~cm}^{-1}$ that was assigned to the stretching vibration, $v_{(\mathrm{B}-\mathrm{H})}$, of the B-H group. The $\mathrm{C}=\mathrm{N}$ group stretching frequency, $v_{(\mathrm{C}=\mathrm{N})}$, occurs at $1537 \mathrm{~cm}^{-1}$, and the $\mathrm{C}-\mathrm{N}$ group stretching frequency, $v_{(\mathrm{C}-\mathrm{N})}$, occurs at $1028 \mathrm{~cm}^{-1}$. At $978 \mathrm{~cm}^{-1}$ band due to $\mathrm{N}-\mathrm{N}$ group stretching frequency, $v_{(\mathrm{N}-\mathrm{N})}$. The bands at 2862, 2925 and $2960 \mathrm{~cm}^{-1}$ can be attributed to the stretching vibrations of the aliphatic and aromatic $\mathrm{C}-\mathrm{H}$ groups.

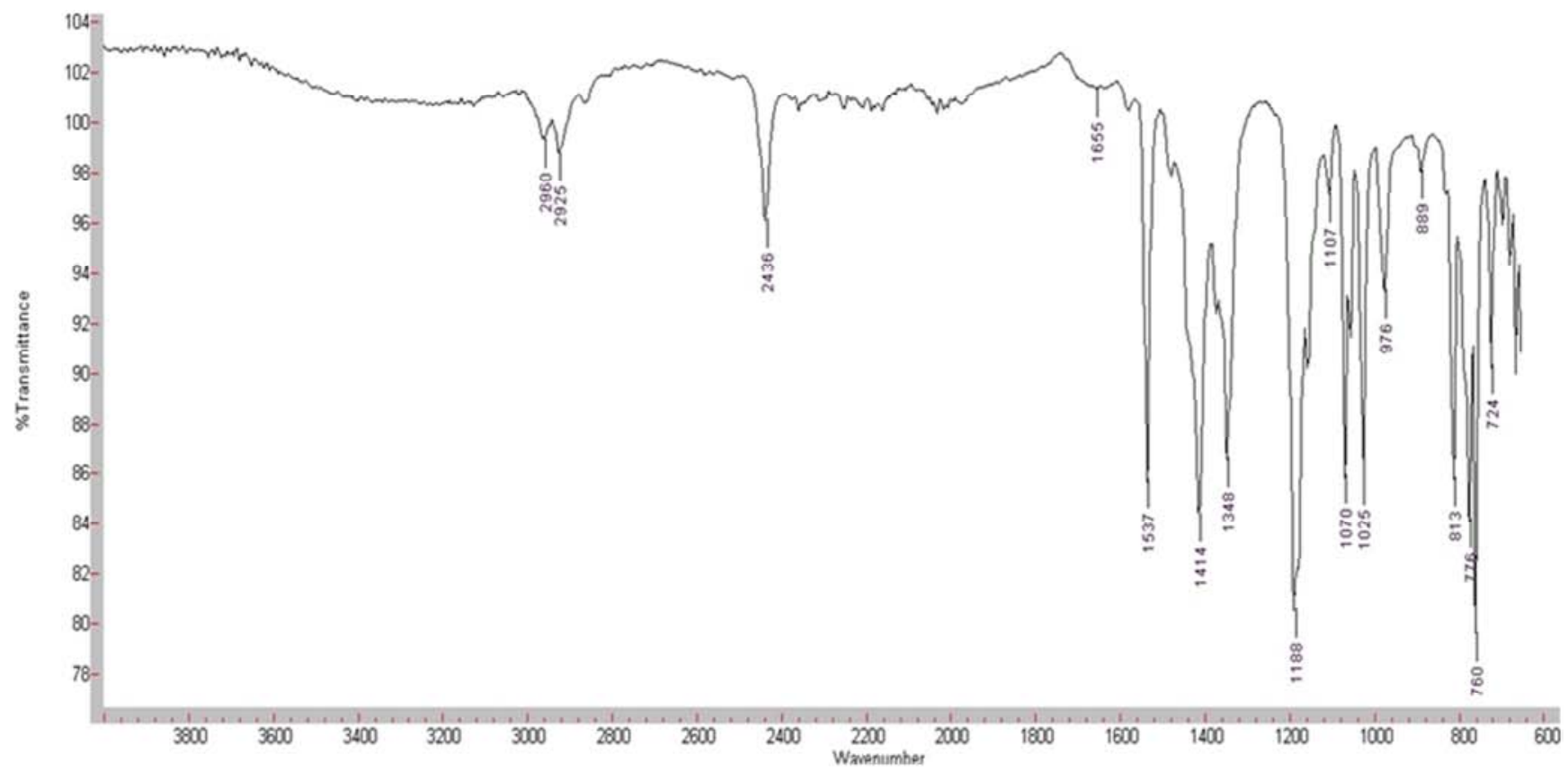

Figure 2. Infrared spectrum of (KTp*) At 1000 and 900 watt.

The IR spectra of Tp* complexes, H1 to H3, figures 3, 4 and 5, respectively, are characterized an absorption band that occurs in the range $2507-2513 \mathrm{~cm}^{-1}$, as a single neat peak, due to $v_{(\mathrm{B}-\mathrm{H})}$ stretching, table 3 . The bands due to the 'breathing' of the pyrazole rings in the complexes occurred at unusually high frequencies, in the range between 1540 and $1630 \mathrm{~cm}^{-1}$. The $v_{(\mathrm{M}-\mathrm{N})}$ and $v_{(\mathrm{M}-\mathrm{Cl})}$ stretching absorptions expected between 200 and $400 \mathrm{~cm}^{-1}$ were not observed because the infrared spectra were recorded from 600 to $4000 \mathrm{~cm}^{-1}$.

Table 3. IR data of $T p *$ complexes $H 1$ to $H 3$.

\begin{tabular}{llll}
\hline Complex & $\mathbf{v}_{(\mathbf{B}-\mathbf{H})}$ & $\mathbf{v}_{(\mathbf{C}=\mathbf{N})}$ & $\mathbf{v}_{(\mathbf{C}-\mathbf{N})}$ \\
\hline $\mathrm{KTp} *-\mathrm{K} \mathrm{BH}\left(\mathrm{C}_{5} \mathrm{H}_{7} \mathrm{~N}_{2}\right)_{3}$ Ligand & 2436 & 1537 & 1028 \\
$\mathrm{H} 1-\mathrm{BH}\left(\mathrm{C}_{5} \mathrm{H}_{7} \mathrm{~N}_{2}\right)_{3} \mathrm{CoCl}$ & 2511 & 1541 & 978 \\
$\mathrm{H} 2-\mathrm{BH}\left(\mathrm{C}_{5} \mathrm{H}_{7} \mathrm{~N}_{2}\right)_{3} \mathrm{NiCl}$ & 2512 & 1542 & 1056 \\
$\mathrm{H} 3-\mathrm{BH}\left(\mathrm{C}_{5} \mathrm{H}_{7} \mathrm{~N}_{2}\right)_{3} \mathrm{CuCl}$ & 2513 & 1541 & 1055 \\
\hline
\end{tabular}




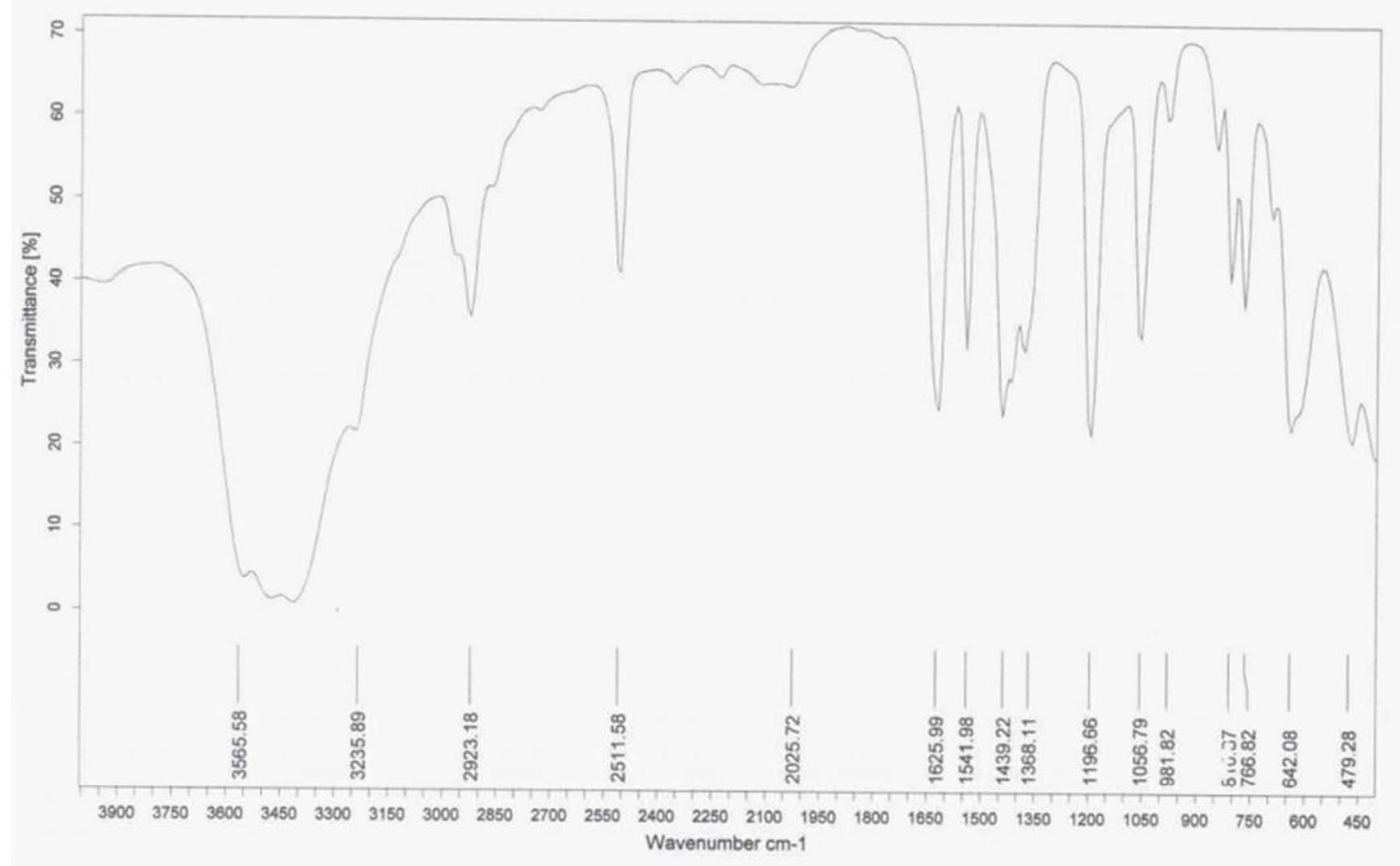

Figure 3. Infrared spectrum of ( $\mathrm{Tp}^{*}$ - Co) complex (H1).

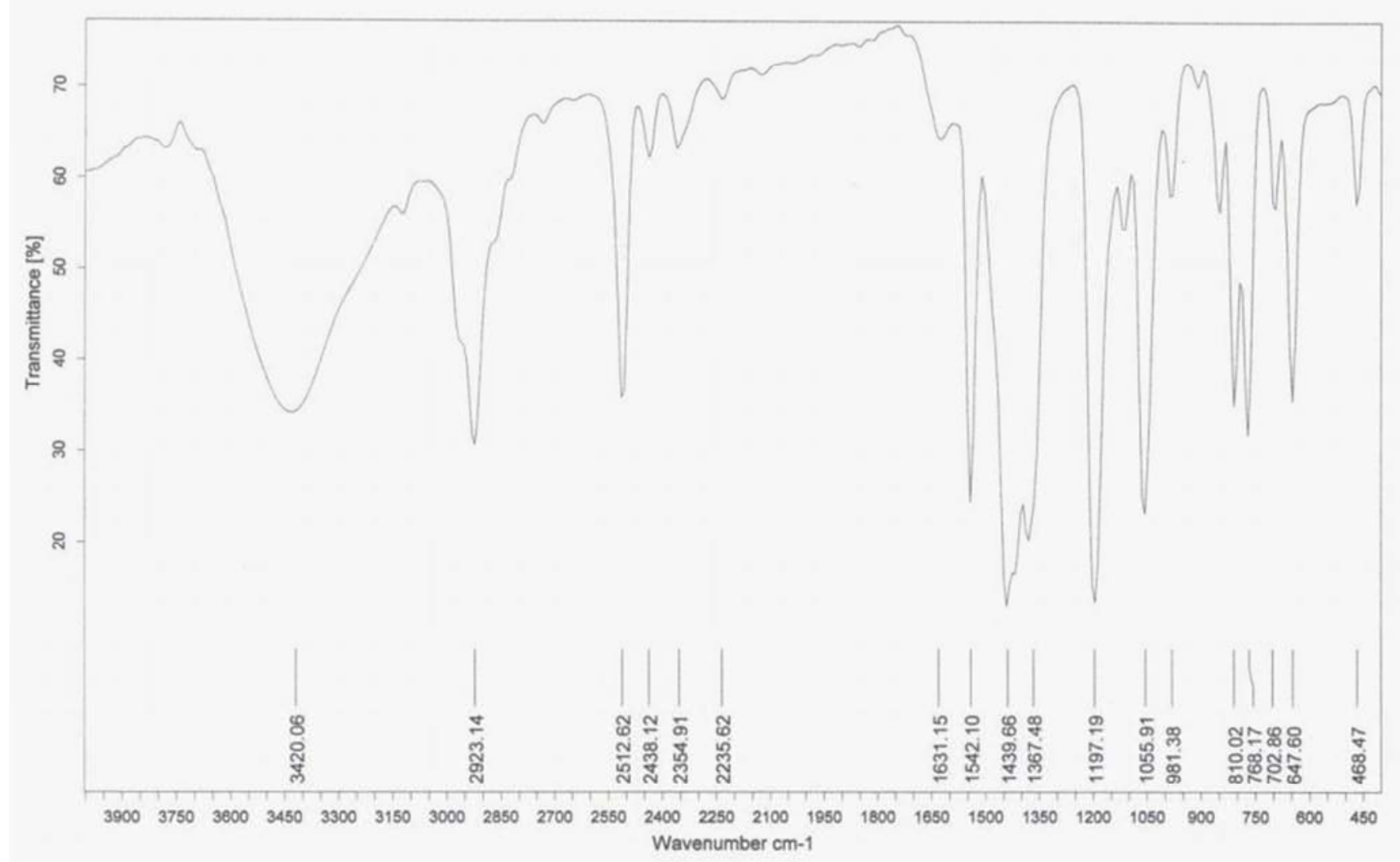

Figure 4. Infrared spectrum of ( $\mathrm{Tp}^{*}$ - Ni) complex (H2). 


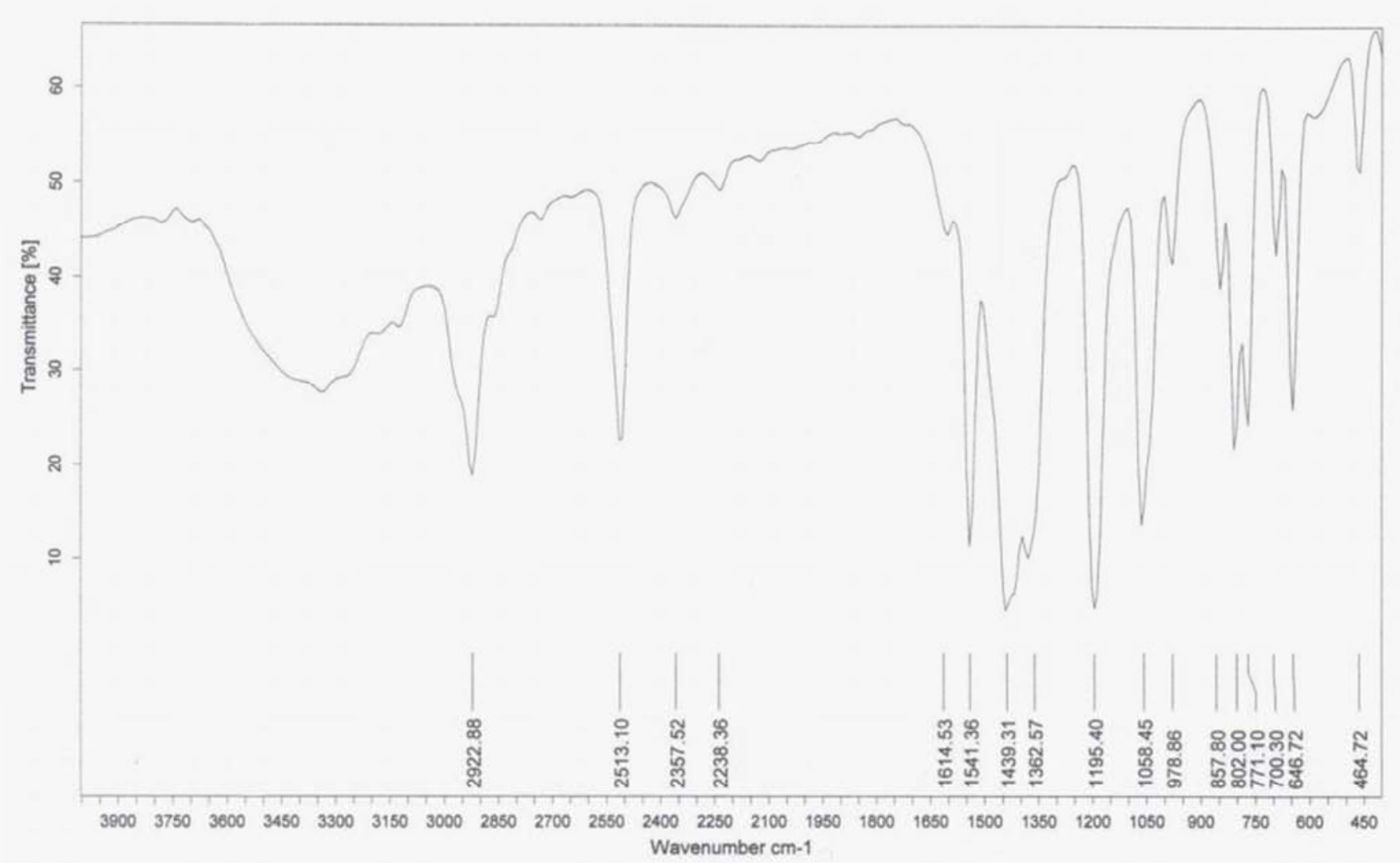

Figure 5. Infrared spectrum of (Tp*- $\mathrm{Cu})$ complex (H3).

\subsection{Elemental Analysis Data}

Elemental analysis of carbon, hydrogen and nitrogen was used in the characterization of all of the complexes synthesized in this work. The experimental and calculated $\mathrm{C}, \mathrm{H}$ and $\mathrm{N}$ contents for these complexes are presented in the table 4 .

Table 4. Elemental analysis data of complexes $\mathrm{H} 1$ to $\mathrm{H3}$.

\begin{tabular}{lllll}
\hline \multirow{2}{*}{ Complex } & \multicolumn{3}{c}{ Elemental analysis } \\
\cline { 2 - 5 } & & $\mathbf{C}$ & $\mathbf{H}$ & $\mathbf{N}$ \\
\hline \multirow{2}{*}{$\mathrm{H} 1-\mathrm{BH}\left(\mathrm{C}_{5} \mathrm{H}_{7} \mathrm{~N}_{2}\right)_{3} \mathrm{CoCl}$} & Cal. & 46.01 & 5.66 & 21.46 \\
& Found & 46.03 & 5.75 & 21.58 \\
$\mathrm{H} 2-\mathrm{BH}\left(\mathrm{C}_{5} \mathrm{H}_{7} \mathrm{~N}_{2}\right)_{3} \mathrm{NiCl}$ & Cal. & 46.04 & 5.67 & 21.48 \\
& Found & 46.04 & 5.67 & 21.48 \\
$\mathrm{H} 3-\mathrm{BH}\left(\mathrm{C}_{5} \mathrm{H}_{7} \mathrm{~N}_{2}\right)_{3} \mathrm{CuCl}$ & Cal. & 45.47 & 5.60 & 21.21 \\
& Found & 46.09 & 5.69 & 21.22 \\
\hline
\end{tabular}

\section{Conclusion}

The synthetic and characterization results obtained in this work lead to the conclusion that the ( $T p^{*}$ complexes $)$ can be synthesized in a solid form using reflux and microwave method in a 1:1 ratio between metal chloride and (KTp*). The microwave method was easier than reflux method and it gives higher percentage yield, and saves time and solvent.

\section{References}

[1] H. R. Bigmore, S. C. Lawrence, P. Mountford and C. S. Tredget, Dalton Trans. (2005) 635-651.
[2] S. Trofimenko, A. Cingolani, C. Pettinari, Science and Technology 86(2004) 94-100.

[3] S. Trofimenko, J. Am. Chem. Soc., 89 (1967) 3165.

[4] S. Trofimenko, J. Am. Chem. Soc., 89 (1967) 4948.

[5] K. Michiue, R. F. Jordan, Organometallics 23 (2004) 460-470.

[6] R. G. Lawrencea, Christopher J. Jonesa, R. A. Kresinski, Inorg. Chim. Acta 285 (1999) 283-289.

[7] M. Herberhold, G. Frohmader, T. Hofmann, W. Milius, J. Darkwa, Inorg. Chim. Acta 267(1998)19-25.

[8] Y.-H. Xing, Bao-Li Zhang, Y.-H. Zhang, H.-Q. Yuan, Z. Sun, Mao Fa Ge, Polyhedron 26 (2007) 3037-3044.

[9] C.-H. Li, J.-D. Chen, L.-S. Liou, Ju-Chun Wang, Inorg. Chim. Acta 269 (1998) 302-309.

[10] M. Cano, J. A. Campo, J. V. Heras, E. Pinilla, Polyhedron15(1996)1705-1715.

[11] C. Manzur, D. Carrillo, F. Robert, P. Gouzerh, P. Hamon, J.-R. Hamon, Inorg. Chim. Acta 268 (1998) 199-204.

[12] A. A. Eagle, G. N. George, E. R. T. Tiekink, C. G. Young, J. Inorg. Biochem. 76 (1999) 39-45.

[13] J. C. Dewar, A. S. Thakur, W. W. Brennessel, M. Cafiero, L. W. Peterson, W. T. Eckenhoff. Inorganica Chimica Acta. 473 (2018) 15-19.

[14] L. Serpasmm, R. R. Baum, A. McGheem, I. INieto, K. L. Jernigan, M. Zeller, G. M. Ferrence, D. L. Tierney, E. T. Papish. Polyhedron. 114 (2016) 62-71. 
[15] J. Masternak, M. Z. Machnik, K. Kazimierczuk, B. Barszcz. Polyhedron. (2018) 93-104.

[16] P. A. Petrov, A. I. Smolentsev, A. S. Bogomyakov, S. N. Konchenko. Polyhedron. 129 (2017) 60-64.

[17] D. Adam, Nature 421 (2003) 571-572.

[18] R. Gedye, F. Smith, K. Westaway, H. Ali, L. Baldisera, L. Laberge, J. Rousell, Tetrahedron Lett. 27 (1986) 279-282.
[19] R. J. Giguere, T. L. Bray, S. M. Duncan, G. Majetich, Tetrahedron Lett. 27 (1986) 4945-4958.

[20] C. O. Kappe Angew. Chem. Int. Ed. 2004, 43, 6250 -62846H. V. R. Dias, X. Wang, Polyhedron 23 (2004) 2533-2539.

[21] Microwave Assisted Synthesis of Potassium Hydrotris (3,5dimethyl-1H-pyrazol-1-yl) borate (KTp*). Hussain Ibrahim Alarabi and Hamed Aboagila Alqamoudy. University Bulletin - ISSUE No.16- Vol. 1 February (2014) 83-102. 